\title{
Kernos
}

Revue internationale et pluridisciplinaire de religion grecque antique

17 | 2004

Varia

\section{Cults on Mount Ithome}

\section{Petros Themelis}

URL: http://journals.openedition.org/kernos/1406

DOI: 10.4000/kernos. 1406

ISSN: 2034-7871

\section{Publisher}

Centre international d'étude de la religion grecque antique

Printed version

Date of publication: 1 January 2004

ISSN: 0776-3824

\section{Electronic reference}

Petros Themelis, "Cults on Mount Ithome », Kernos [Online], 17 | 2004, Online since 22 April 2011, connection on 01 May 2019. URL : http://journals.openedition.org/kernos/1406 ; DOI : 10.4000/ kernos. 1406 


\section{Cults on Mount Ithome}

\section{Zeus Child}

Spyros Marinatos and Paul Faure have supported the view that the legend of Zeus child was introduced to Crete by the Peloponnesian colonists of LH III. ${ }^{1}$ Most scholars however, Charles Picard, Robert Willetts and James Laager among them, have argued in favour of the Cretan priority. ${ }^{2}$ Madeleine Jost considers as vain the discussion in favour of the Cretan or the Peloponnesian priority of the myth of Zeus child. According to her also the subject of a goddess being accompanied by armed "propoloi" like the Kouretes is frequent in the Aegean. ${ }^{3}$ However, the introduction of the cult of Zeus from Crete via the island of Kythera cannot be easily denied, according to my opinion. Who introduced the cult and why are problems not to be discussed here.

Hugh Sackett and MacGillivtay would like to see Zeus Velkhanos in the "Greatest Kouros", as they call the Minoan statuette of a standing young god in gold, ivory, serpentine, and rock crystal found 1989 in a destruction layer of LM IB (about 1450 B.C.) at Palaikastro." The English scholars go as far as to suggest that their excavations at Palaikastro have produced unexpected evidence that the Minoans also worshiped a youthful male divinity whose cult could be the basis for the later Greek cult of the Zeus Kouros, or Zeus as a youth. ${ }^{5}$ In the old excavations of Palaikastro the ivory statuette of a crouching child as well as a second one of a seated boy have been found. A clay seal impression from the same excavation bears a rare representation of the "Master of Animals" in an early form of "Zeus the Thunderer"." A seal impression from Knossos shows a boy beneath a sheep. 'The ivory group of tow women and a boy, known as the "Ivory Trio", from the shrine deposit of

\footnotetext{
1 S. Marinatos, "Die Wanderung des Zeus", AA (1962), p. 907-916; P. Faure, Fonctions des cavernes crétoises, Paris, 1964, p. 120-123.

${ }^{2}$ Ch. PICARD, Eléments orientaux dans la religion grecque ancienne, Paris, 1960 , p. 168; R.F. WILLETTS, Cretan Cults and Festivals, London / New York, 1962, p. 218; J. LAAGER, Gebunt und Kindbeit des Gottes in der griechischen Mythologie, 1975, p. 173-178 and 191-194.

3 M. JOST, Sanctuaires el cultes d'Arcadie, Paris, 1985, p. 248-249.

4 H. SACKET T and S. MaCGILLIVRaY, "Boyhood of a God", Archoreology 42.5 (1989), p. 26-31; J.A. MaCGillivay, L.H. SACkET, J.M. Driessen (eds.), The Plaikasiro Kouros, a Minoan Cbryselephantine Statuelle and its Bronze Age Contew, London, 1999, p. 121-147.

5 SACKetT - MaCGillivray (supra n. 4), p. 29.

"rbid., p. 30- 31 .

7 A. Evans, The Mycenean Tree and Pillar Cult, London, 1901, p. 31, fig. 17; M.P. NiLsson, Minoan-Mycenaean Religion, Lund, 1950, p. 540, fig. 205.
} 
the palace area at Mycenae (Athens Nat. Mus. inv. no. 771) has been interpreted by some scholars as representing divine Nurses and the child Zeus of Crete. ${ }^{8}$

The cult of Zeus in the Ida cave, according to the finds of the earlier and the more recent excavations, begins in the $8^{\text {th }}$ century B.C.' as it does at Messene, the example of Eleithyia (her cult in Amnisos cave) however "argues for at least a partial continuity from Minoan to Greek", as Burkert notes." There also seems to be continuity of the cult in Velchanos sanctuary at Aghia Triada. ${ }^{11}$ Velkhanos is the Cretan name of Zeus child or boy, according to Hesychius (s.v.). Young Zeus, Velchanos is depicted on the Fortetza lid walking to the right and holding the thunderbolt in his right and a bird in his left hand. ${ }^{12}$ In the known hymn from Palaikastro, youths, in their war dance, invoke Zeus as Vellkhanos, the greatest Kouros to come to Dikte, birthplace of Zeus, to spring in flocks, fields, towns, ships and new citizens. ${ }^{13}$ Velkhanos appears on coins of Phaistos and Lyttos as a young beardless man seated in front of the Ida cave with a bird, probably a cock on his knees, similar in age but not in pose to the young striding "Kouros Megistos" on the coins from Aigion. ${ }^{14}$ Roof-tiles from Aghia Triada bearing the name Velkhanos, indicate the place above the ruins of the Minoan palace where the temple of Zeus

${ }^{8}$ H. WACE, Ivories from Wycenae, no.1: The Ivory Trio, Athens, 1961; G. KORREs, " $\Delta . \pi \lambda \alpha$ i

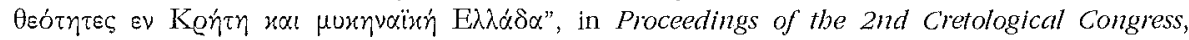
Athens, 1968 , p. 117, no. 1-2; E.T. VERMEULE, Arcbaeologica Homerica III, v: Gölterkult, Göttingen, 1974, p. 53, pl. V, III a,b with bibliography; c/. K. PILAFIDIS-WILLIAMs, The sanctuary of Aphala on Aigina in the Bronze Age, München, 1998, p. 144, who is wondering if the Ivory-Trio could represent the two aspects (mother and virgin) of one and the same goddess and the divine child.

9 J.A. SAKELlaraKIS, "Some Geometric and Archaic votives from the Idaean Cave", in R. HÄGG, N. MARinatos, G.C. NORdQuist (eds.), Early Greek Cult Practices, Proceedings of the 5th Intemational Symposium at the Swedish Institute at Athens, 26-29 of June 1986, Stockholm, 1988, p. 173-193.

10) W. Burkert, Greek Religion, Cambridge, 1985, p. 26.

11 D. LEV, ASAtene 3-5 (1941/43), p. 52-69; BuRKERT (supia n. 10), p. 48, n. 17.

12 D. LEVI, "Cleanings from Crete", A/A 49 (1945), p. 310, fig. 20; J.K. Brock, Fortetsa, Cambridge, 1957, no. 1414́, pl. 107, II.

13 H. Jeanmare, Comroi et Conretes, Lille, 1939, p. 430-432; P.J. PerLian, "Invocatio and Imprecatio: The Hymn to the Greatest Kouros from Paliakastro and the Oath in Ancient Crete", JIHS 115 (1995), p. 161-167; WILLETTS, (supra n. 2), p. 169-170 and 172; M.L. WEST, "The Diktaean Hymn to the Kouros", JFIS 85 (1965), p. 149-159; N. ROBERTSON, "The Ritual Background of the Dying God in Cyprus and Syro-Palestine", HThR 75 (1982), p. 313-359; SACKETT - MACGILLIVRY (supra n. 4), p. 26-31; P. DIKAIOS, "A Terracotta Relief from Marion and the Palaikastro Hymn", Kadmos 1 (1962), p. 139-140.

${ }^{14}$ G. Le RIDER, Monnaies crétoises du $V^{r}$ au $I^{\prime r}$ siècle av. J. C., Paris, 1966, p. 91, nos. 38-40, pl. XXII, 20-24 and 143-149 and 195; J.N. Svoronos, Numismalique de la Crète ancienne, Macon, 1890 , s.v. Gortyne, p. 161-172, nos. 26-31, 34-36, 51-78, 81-86, 98-106; G. CAPDEVILLE, "L'Oracle de l'Ida crétois", Kernos 3 (1990), p. 89-101, fig. 1, who argues in favor of the oracular function of the Velkhanos cult in the Ida cave; B.V. HEAD, Hisioria Numorum, a Manual of Greek Numismatics (Reprint Oxford, 1964), 473, fig. 273; Ch. SELTMAN, Greek Coins., London, 1970, pl. XXXVIII 1; A.B. CoOK, Zeus, II, p. 946; WILIETTS (supra n. 4), p. 177ff; P.R. Franke, M. Hirmer, Die griechiscbe Mïnze, München, 1964, fig. 167. 
Velkhanos was built. ${ }^{15}$ A month Velkhanios or Elchanios is reported in $7^{\text {th }}-6^{\text {th }}$ century inscriptions from Gortys. ${ }^{16}$ The name of Spring Festivals Velkhania associated with this month is found at Lyttos in an inscription as late as the $2^{\text {nd }}$ or $3^{\text {rd }}$ century A.D. ${ }^{17}$ The name Voulkanos is still used, as stated above, to denote the summit of mount Ithome, especially in connection with the old monastery and the post-byzantine church of Virgin Mary with her miraculous icon, constructed with spolia on the actual place of Zeus Ithomatas' sanctuary. Despite my detest for "old-fashioned" etymological speculations, I would like to draw attention to a possible connection of Voulkanos with Velkhanos. ${ }^{18}$ "Although the many broken lines of tradition and innumerable catastrophes of early times cannot be lightly overlooked, forces of continuity have always reasserted themselves, and probably nowhere as much as in the sphere of religion." "19

A portable cult image made of bronze was much later, in the classical period, introduced to Messene from central Greece. The perieget Pausanias who visited Messene in the period of Antoninus Pius (155-160 A.D.) writes the following about the sanctuary of Zeus Ithomatas (IV, 33, 1-2):

On the way to the summit of Ithome, the acropolis of Messene, there is a spring called Clepsydra. It would be impossible to enumerate, even if one wanted to do so, all those who would like Zeus to have been born and brought up in their own country. The Messenians are among them, too. They say that the god was brought up here (in Messene) and nursed by the Nymphs Ithome and Neda; it was from Neda that the name of the river derives, while the other Nymph, Ithome, gave her name to the mountain. When the Kouretes abducted Zeus, to save him from his father, they were those Nymphs who bathed Zeus here and the spring was named Clepsydra after the klope (steeling) of Zeus by the Kouretes. Every day they carry water from the spring to the sanctuary of Zeus at Ithome. The statue of Zeus is a work of Ageladas and was originally made for those Messenians settled in Naupactos. An annually elected priest keeps the statue in his house. They also celebrate an annual festival called Ithomaea; in the old times they used to perform a musical contest as well, this can be assumed by the verses of Eumelos.

Pausanias' account on the cult of Zeus-child at Aigion, a cult in many aspects similar to that of Zeus at Messene, is of importance for our discussion:

The people of Aigion possess several bronze statues, one of them represents Zeus as a child and another Heracles also as beardless youth, both made by the

${ }^{15}$ M.P. Nusson, Geschichle der griechischen Religion I, München, 1967, p. 300.

${ }^{16} B C H$ (1905), p. $204 \mathrm{ff}$.

17 BCH (1899), p. 61f, no. 6; WILLETTS (supra n. 2); M. GuARDUCCI, Inscripliones Creticae I, Roma, 1935, Lyttos, XVIII, 190-191, inscr. no. 11, v. 3; ead., IC IV, Tiluti Gortynit, inscr. no. 3, v. 1

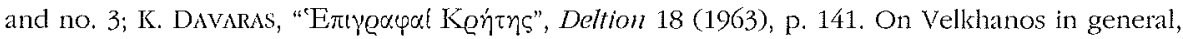
see G. CAPDEVILLE, Volcanus, Rome, 1995, passim.

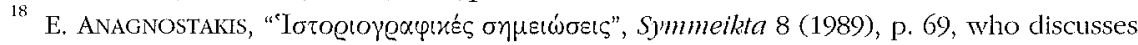
almost all up to now proposed etymologies of the word Voulkanos without refering to Velkhanos.

19 BURKERT (supra n. 10), p. 15. 
Argive Ageladas. For both gods two priests are elected every year, each one of them keeps a statue in his house; in more ancient times, the most beautiful boy was chosen to be priest to Zeus, but when his beard began to grow this award for beauty was transferred to another boy (Paus., VII, 24, 4).

Most scholars accept that the statue of Zeus, which the Argive sculptor Ageladas (or Hageladas) ${ }^{2 \prime \prime}$ had made for Aigion, was illustrated on bronze coins of the city issued in the period of Septemius Severus, Caracalla and Geta (late $2^{\text {nd }}$ - early $3^{\text {nd }}$ C. A.D.). ${ }^{21}$ On these coins the young beardless god appears striding to the right, holding a thunderbolt in his raised right hand and carrying the eagle on his outstretched left. ${ }^{22}$ The words AIGIEON PAIS and MEGAS written around the image of Zeus on some of the coins, leaves no doubt about his identification with "Kouros Megistos" and his relation to Crete.

On some of the coins Zeus is depicted as a crouching infant suckling beneath the she-goat Amaltheia. ${ }^{23}$ The same iconographical type is used for the representation of Heracles infant on silver coins from Thebes, or the child Arkas on coins issued at Mantinea in Arcadia. One of the two statues of Zeus at Aigion should have been of small size and portable, periodically moved from the temple to the house of the priest. The iconographic motif of an infant nursed by an animal appears in Minoan times and extends down to the Roman period. On a seal from Knossos, for example, a goat is nursing a child, a divine child according to Martin Nilsson. ${ }^{2.4}$ Manolis Stefanakis provides most of the relevant depictions on coins, gems and various works of art. ${ }^{25}$ On staters of Praisos issued in the $4^{\text {th }}$ century B.C. a cow identified with Io is suckling an infant thought to be Zeus. ${ }^{26}$ Telephos being suckled by a hind or

20 Ageladas from Argos had made statues of victorious athlets in Olympia, statues of gods and a Muse, as well as a monument combining bronze horses and captive women. He was probably active in the period 520-508 B.C., Pliny's date, NI XXXIV, 49, of his floruit (87th Olympiad) is too low; cfr. the inscription "IVO no 631 " of about 500 B.C.; G.E. MYLONAS, "The bronze statue from Atemision', $A / A 48$ (1944), p. 143-160; C.A. RoBINson, Jr., "The Zeus Ithomatas of Ageladas", AJA 49 (1945), p. 121-127; C.C. MATTUSCH, Greek Bronze Statuary from the Beginnings tbrough the Fifth Century B.C., Ithaka / London, 1988, p. 139.

21 J.H. Krolt, "Bronze coinage of Roman Aigion", NumChron 156 (1996), p. 49-78.

${ }^{22}$ HEAD (supra n. 14), p. 431

${ }^{23}$ F.W. IMHOOF-BLUMER - P. GARDNER, Ancient Coins illustrating Lost masterpieces of A $\%$ A Numismatic Commentary to Pausanias (reprinted by A. Oikonomides), Chicago, 1964; $c f$. T. HADZISTELIOU-PRICE, "The Type of the crouching boy and the "Temple Boy", ABSA 64 (1969), p. 95-96, pl. 20,1; S. MARINATOS - M. HIRMER, Kreta, Thera und mykenisches Hellas, München, 1973, pl. 113: crouching infant made of ivory fom Palaikastro; Chr. Vorster, Griechische Kinderstatuen, Köln, 1983, p. 189-210.

24 Nilsson (supra n. 15), p. 321, pl. 26, 6. The lack of representations from LM to Archaic speaks of course against any indigenous iconographic continuity; it seems that the motif was reintrocluced under Eastern influence.

${ }^{25}$ M.I. STEFANAKIS, "Kydon the oikist or Zeus Gretagenes Kynotraphes? The Problem of Interpreting Cretan Coin Types", Eulimene 1 (2000), p. 81 and note 13 with bibliography.

26 Svoronos (supra n. 14), pl. XXXII, 2; H. WEBEr, "On Some Unpublished or Rare Coins", NC (1896), p. 19; LE Rider (supra n. 14), p. 197. 
a deer is represented on $4^{\text {th }}$ century B.C. coins from Tegea, while Kydon, the eponymous hero-oikist of the city of Kydonia, or Zeus Cretogenes himself appears on $3^{\text {rd }}$ century B.C. coins of Kydonia. ${ }^{27}$

The iconographic types of Zeus seems to be generally related to his main stages of age from childhood to maturity; he is represented: a) as infant or child cartied by the Nymphs-nurses, ${ }^{28}$ or suckling beneath Amaltheia or just crouching alone, b) as a beardless initiated ephebe, as "Kouros Megistos" seated or striding gloriously with the thunderbolt in his hand, c) as a mature bearded man in a pose similar to the previous one or seated on a throne.

A notable iconographic example of Zeus is found on the west pediment of the temple of Artemis Gorgo in Corfu (c. 580 B.C.). Zeus as a beardless naked youth, as Kouros Megistos holding the thunderbolt in his raised right hand attacks a Titan, probably Kronos. ${ }^{29}$ Also in some late Geometric and late archaic Zeus statuettes from Olympia the god appears as beardless youth. ${ }^{30}$ The cult of Zeus in Olympia counts among those related to Crete, Ida cave, Eileithyia, the Idaean Daktyloi and the Kouretes as guardians of the divine child (Paus., V, 7, 6 and VI, 20, 1-6). ${ }^{31}$ Among various female deities worshiped at the foot of Kronos hill at Olympia was also Eileithyia. ${ }^{32}$

Two votive bronze statuettes in the "striding-god" type found in the sanctuary of Heracles, the so-called "Pyra" on the summit of mount Oite, are of importance to our discussion as far as the age differentiation in the iconography of the god is concerned. One of them, dated to the $6^{\text {th }}$ century B.C., represents the god as a beardless youth, while the second, of the early $5^{\text {th }}$, as a bearded adult. Both are iconographically identical to the "Blitzschwinger" Zeus. ${ }^{33}$

27 BMC Peloponnesus 202, pl. XXXVII, 16-17, 21; cf. C. BAUCHHENSS-THUEREDL, Der Mjthos von Telephos in cler antiken Bildkunst, Würzburg, 1971, p. 78; STEFANAKIS (supra n. 16), p. 83-84.

${ }^{28}$ As it happens with the infants Hemes or Dionysos been carried by adult figures: $\mathrm{T}$. STEFAnidou-Tiveriou, Neoattika, Athens, 1979, p. 33, no. 48f, pl. 35-37; H. Froning, Marmorschmuckreliefs mit griechischen Wytben im 1. Jh. v. Chr., Mainz am Rhein, 1981, p. 54, pl. 5.2.

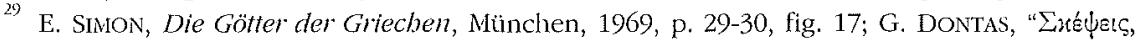

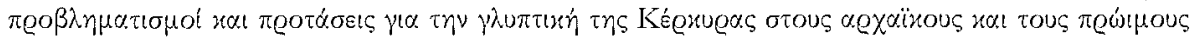
xhaouoús yeóvous", in B. Petrakos (ed.), EPAINOS for J. Papademiliou, Athens, 1997, p. 52-164, esp. 130, fig. 62 with bibliography.

3.1 A. MaLLwTZ, Olympia lind seine Bauten, München, 1972, p. 22-23, fig. 11.

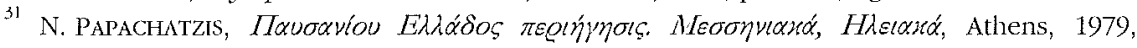
p. 372-373, note 1; S. Piniatoglou, Eileilhyia, Würzburg, 1981, p. 40, fig. 2.

32 H.-V. HERMANN, "Zur ältesten Geschichte von Olympia", MDAI(A) 77 (1962), p. 12.

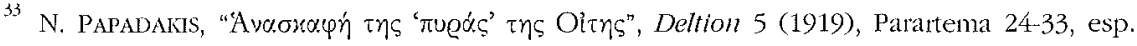
30-31, figs, 6a, b-7a, b; Papadakis is aware of the iconographic identity of his statuettes to the Zeus Ithomatas type, that is why he refers to Hageladas and his statue of the young Heracles in

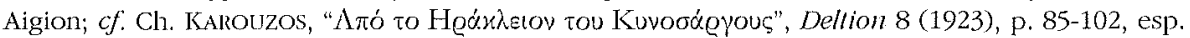
93 with note 1; cf. MatTusch (supra n. 20), p. 114, fig. 5.11 (striding god from Mantinea in Paris

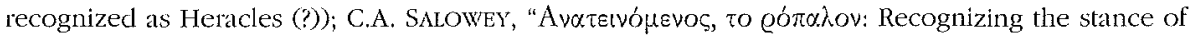
Herakles", AJA 97 (1993), p. 299; A.L. KUTTNER, Dynasty and Empire in the Age of Alugustus: The Case of the Boscoreale Cups, Berkeley / Los Angeles, 1993, fig 26; C. MATTusch, The Victorious 
The use of small movable figures in the cult "may in principle be older than the setting up of cult images in temples", while portable figures were usually not iconographically identical with the firmly fixed cult statues, ${ }^{34}$ Movable cult figures, in most of the cases we know, coexisted side by side with "immovable" large size cult statues. This seems to have been the case not only with Zeus at Aigion and Ithomatas at Messene, but also with Artemis Orthia at Messene. The small portable wooden cult image (xoanon) of Orthia existed side by side with the colossal marble cult statue of Artemis Phosphoros, a work of Damophon. The portable cult image was used in cult practices and initiation rites and carried by female initiates. ${ }^{35}$ In Sparta the xoanon of Orthia was carried by the priestesss herself during the bloody ritual (Paus. 3.16.10). The famous statue of Athena Polias on the Athenian Acropolis was a small xoanon made of wood light to bear (Paus., I, 26, 6). It was carried to the sea covered with a veil during the fest of Plynteria (Xenophon, Hell. I, 4, 12). ${ }^{36}$

The statue of Zeus Ithomatas made by Ageladas for the Messenians settled at Naupaktos, said to have been brought to their new capital by the old priestly families when they returned to Messene from the exile in 369 B.C.; it was also portable according to Pausanias' account, ${ }^{37}$ On coins of the city issued in the $4^{\text {th }}$ century B.C. Ithomatas appears in striding pose with the thunderbolt in his raised right and the eagle on his extended left hand. ${ }^{38}$

The type of striding Zeus with the thunderbolt in his raised right hand (Keraunios, Kataibates) appears in the iconography of the late 6th and early $5^{\text {th }}$ century B.C. and later mainly in Messapia, Illyria, Epirus, Aetolia ${ }^{39}$ and Elis-

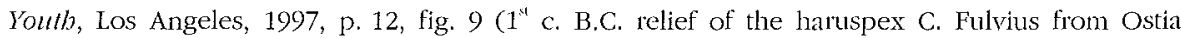
showing fishermen lifting a stricling Heracles' statue in their nets).

34 BURKERT (supra n. 10), p. 90.

35 P. THEMELIs, "Artemis Ortheia at Messene, the Epigraphical and the Archaeological Evidence", in R. HäGG (ed.), Ancient Greek Cull Practice from the Epigraphical Evidence. Intern. Seminar at the Swedish Institute at Albens 22-24 November 1991, Stockholm, 1994, p. 101-122.

${ }^{36}$ N. PAPACHATZIS, "The Cult of Erechtheus and Athena on the Acropolis of Athens", Kernos 2 (1989), p. 177. Contra M. CHRistopoulos, Kennos 5 (1992), p. 27-39.

${ }^{37}$ Cook, Zeus (supra n. 14), II 1 (Cambridge, 1925), p. 741 and II 2 (1940), p. 1153; G.W. Elderkin, "Bronze statuettes of Zeus Keraunios", A/A 44 (1940), p. 225-233; C.A. Robinson, "The Zeus Ithomatas of Ageladas", $A / A 49$ (1945), 121-127 (we have to note that the floruit period of Ageladas (late $6^{\mathrm{l}_{1}}$ - early $5^{\text {th }}$ c. B.C.) does not accord well with the period the Messenians were settled at Naupactos (PAus., IV, 31, 7); W.H. Gross, "Kultbilder, Blitzschwinger and Hageladas", $R b M 70$ (1963), p. 13; id., RE X A (1972), col. 316, s.v. Epiklesen; H. SvENSON-EvErs, "IEROS OIKOS. Zum Ursprung des griechischen Tempels", in W. HÖPFNER (ed.), Kult und Kultbauten aul der Akropolis, Internationales Symposion vom 7. bis 9.Juli $1995 \mathrm{in} \mathrm{Berlin,} \mathrm{Berlin,} \mathrm{1997,} \mathrm{p.} 145$ and 147-148.

38 BMC, Peloponnesos, 109-11, pl. XXII, 10, 11, 15; IMHOOF-BLUMER - GARDNER (supra n. 23), p. 67; HEAD (supra n. 14), p. 431, fig. 236.

39) C. ANTONETTI, Les Etoliens. Image et religion, Paris, 1990, p. 224-225, pl. 20, 2, thinks that the statuette comes from Naupaktos and not Amvrakia, the village in Aetolia where K. Rhomaios actually found it. 
Olympia", in an area with common cultural traits to which West Locris, Achaia and Messenia also belong. ${ }^{41}$ It should be noted here that the type of a striding aggressive god recognized as a weather god had a long tradition in the iconography of the Orient. Morover statuettes of the Syro-palestinian god Reshef, which seem to follow this tradition, have been found in various sanctuaries in Greece. ${ }^{42}$ Of special importance is a silver statuette of the Striding Zeus type of the Late Bronze Age in the Ashmolean, probably of Hittite origin, found in Kallipeuke at Lower Olympus. ${ }^{13}$ Oliver Smith drew

40) E, Kunze, "Kleinplastik aus Bronze", Olympia Berichl VI, Berlin, 1961, p. 138-180 and 145151, pl. 60-61.

N. Degrassi, "Lo Zeus Stilito di Ugento", Archaologica 25 (1981), p. 32; R. WÜNSCHF, "Der

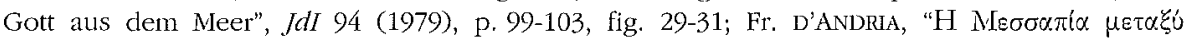

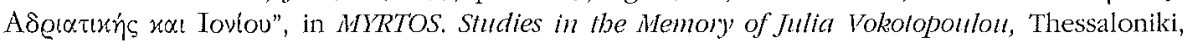
2000 , p. 46, fig. 10, who interprets the statue as an image of Zeus Kataibates; C. CARAPANOS, Dodone et ses mines, Paris, 1878 , p. 32, no. 13, pl. 12, no. 4; K.A. NEugebautr, "Zeus von Dodona", JdI 49 (1943), p. 162-173; W. SCHERING, Die Bronzeslatllelle des Zetis von Dodona, Berlin, 1969, passim; Albanien, Schätze aus dem Land der Skipetaren, Mainz, 1988, p. 378-379, no. 293; S. Karouzou, Illustrated Glide to the Mluseum, Athens, 1977, p. 99; MATTUSCH (supra n. 20), p. 68, fig. 4.17; Ch. Tzouvara-Soul, "Common Cults in Epirus and Albania", in P. CABanes (ed.), L'illyrie méridionale et l'Épire dans l'Anliquité II. Actes du If colloque intenational de

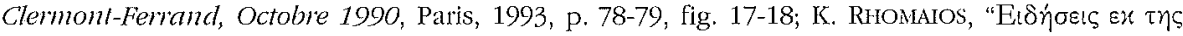

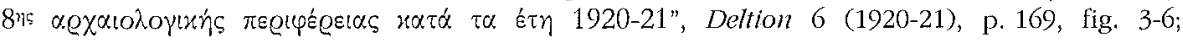
A. FURTWÄNGLER, Die Bronzen und die übrigen Kleinfunde, Olympia IV, Berlin, 1895, p. 46, pl. 7 and 8, nos. 43-44; E. Kunze, Olympiabericht $T$, Berlin, 1944, pl. 51.52; E. KunZE, "Ausgrabungen in Olympia 1962/3", Deltion 18 (1963), p. 110, pl. 146c; cf. P. GARDNER, Calalogue of Greek Coins. Thessaly to Aetolia, Bologna, 1963, p. 109, no. 1, pl. 32, no. 10; O. Ravel, "The Coins of Ambracia", NNM 37 (1928), p. 66-67, no. 139-140, pl. 13; L. LACROIX, Les reproductions de slatles sur les monnaies grecques, la statuaire archaique et classique, Liège, 1949, p. 74; cf. K. WARDLE, "Cultural Groups of the Late Bronze and Ealy Iron Age in North-West Greece", Godesnjak 15 (1977), p. 153-199.

42 H. FrankFORT, The Ant and Architecture of the Ancient Orient., London, 1970, p. 162-163, 256 and 298, fig. 188, 294 and 349; cf. R.D. BARNETT, "Oriental Influences on Archaic Greece", in The Aegean and the Near East. Studies Presented to Hetty' Goldman, New York, 1956, p. 216f; D. CONRAD, "Der Gott Reschef", Zeitschrift fïr die Altestamentliche Wissenschaft 83 (1971), p. 157183; D. Colton, "The Smiting God, a Study of Bronze in the Pomerance Collection in New York", Levanl 4 (1972), p. 111-134; W. BuskFrT, "Resep-Figuren, Apollon von Amyklai und die Erfindung des Opfers in Cypern", GB 4 (1975), p. 64-66; H. SEEDEN, The Standing Armed Figurines in the Levant, Munich, 1980; C. Roller, "Un dieu syrien à Thermos", BCH 108 (1984), p. 669-670; H. Gallet de SANTERre, "Les statuettes de bronze mycéniennes du type dit du "Dieu Reshef" dans leur contexte égéen", BCH 111 (1987), p. 7-29; C.M. KEEsung, The Volive Statues of the Athenian Acropolis, Cambridge, 2003, p. 82. On peak sanctuaries and their relation to the Thundergod, Chr, KaRDara, Ephem (1966), p. $149 \mathrm{ff}$.

Evans (supra n. 7), p. 125-126; cf. P.R. Mooray, "Problems in the Anthropomorphic Metal Statuary from Syro-Palestine before 330 B.C.", Levant 16 (1984), p. 67ff; C. RENFrEW, The Arcbaeology of Cull. The Sanctuary of Pbylakopi, London, 1985, p. $302 \mathrm{ff}$; S.V. CANBr, "Some Hittite Figurines in the Aegean", Hesperia 38 (1969), p. 143-146; P. ADAM-VELENi, E. POULAKI and

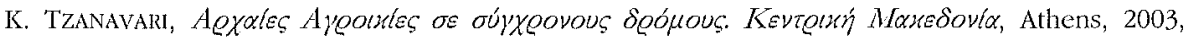
p. 23-24, with colour figure. 
attention to the iconographic connection of this type with statuettes of Zeus from Olympia. ${ }^{*}$

Bronze statues and particularly votive statuettes of this type have been found at various sanctuaries in Western Greece a particularly in Olympia. ${ }^{45} \mathrm{~A}$ striding god appears also on coins of Elis since archaic times. ${ }^{46}$ The type may have originated in Elis (Olympia) where a variety of bronze statuettes of Olympian Zeus in striding pose was reproduced from the Geometric period to the $5^{\text {th }}$ century B.C. ${ }^{47}$ Through the Elean colonies the type was most likely transplanted to Epirus, Illyria and Messapia and used for votive images of the god by cities of the area. The iconography of the striding Zeus is rightly compared to that of Athena Promachos, since both are depicted in vivid action as if participating in a Gigantomachy. On a silver tetradrachm issued in 277/276-239 B.C. by Antigonos II Gonatas (Berlin, Staatliches Münzkabinett) Athena Alkis appears in the form of an archaistic Palladion holding the thunderbolt of her father Zeus in her raised right hand instead of the spear. ${ }^{48}$

Willy Schwabacher advanced the theory that the first cult statue of Zeus in Olympia, before Pheidias, could have been a statue in the type of the striding god. $^{49}$ He based his arguments on the presence of the early statuettes in Olympia and the emblems on Elean coins, on the fact that the type of the striding Zeus existed in monumental size as well, as proved according to him, by the bronze statue of Zeus found in the sea near cap Artemision in North Euboea." However, the type of an aggressive striding god is not appropriate

14 O.P.H. SMITH, "Near Eastern Forerunners of the Striding Zeus", Arcbaeology 15 (1962), p. 176-178.

45 A. GreifEnHAGEN, Antike Kunstwerke, Berlin, 1966, pl. 17-18; SinON (supra n. 29), p. 30, fig. 18 (= bronze statuette of Zeus from Dodona in Berlin-Charlottenburg, um 470 B.C.); KuNZE (supro 11. 41), pl. 60-61.

46 W. SCHABACHER, "Olympischer Blitzschwinger", AnlK 5 (1961), p. 9-17; The type of striding Zeus with thunderbolt appears on Athenian bronze coins of the $2^{\text {nd }}$ - early $1^{\text {it }}$ century B.C.:

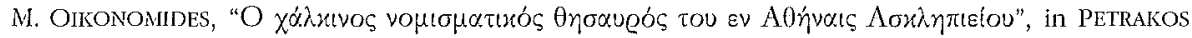
(supra n. 29), p. 217-228, figs 1-2 with bibliography.

47 E. Kunze, "Zeusbilder in Olympia", AuA 2 (1946), p. 100; cf. H.-V. HermanN, "Zum Problem des mykenischen Ursprungs griechischer Heiligtümer: Olympia und Delphi", in Forscbungen zur ägäischen Vorgescbichte, Das Ende der mykeniscben Welt. Akten des inlennationalen Kolloqiums, 7.-8. Juli 1984, Köln, 1987, p. 168, n. 44; S.I. DAKARIs, Cassopaia and the Elean Colonies, Athens, 1971 (Ancient Greek Cities, 4); cf. C. Suerer, "Presupposti della colonizzazione lungo le coste epirote", in CABANEs (supra n, 41), p. 29-39. According to Pausanias (V, 3-5) and Apollodore (XI, 8, 3) Aetolians had setlled in Elis during the Dorian Descent, while in Olympia, a common hero festival of Eleans and Aitolians was celebrated (PAUS., V, 15, 12).

48 SIMON (supra n. 29), p. 192, fig. 175.

49) Schabacher (supra n. 46), p. 9-16.

50 Ch. Karouzos, "O Побєtó́v tou Apteutotov", Dellion 13 (1930), p. 41-104; bibliography up to 1947 in H.G. BEYFN, "Le Poseidon d'Artémision et l'école de sculpture de Sicyone", in H.G. BEyen - W. VOLlgrafF, Algos et Sicyone, Études relatives à la sculphure grecque de style sévère, Paris, 1974, p. 41, note 1; B.S. RIDGWar, The Severe Style in Greek Sculpture, Princeton, 1970, p. 62-63, notes 4-7; WüNSCHE (supra n. 41), p. 77-111; on the chronology see J. KLEINE, "Zur" Daticrung des Poseidon vom Kap Artemision", Feslschrift fïr Gerbard Kleiner, Tübingen, 1919 ,

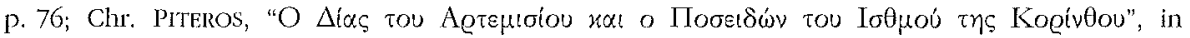


for a cult statue in this early period, not to mention the problem of the material: marble (or ivory) and not metal is usually preferred for the construction of cult statues. Brunilde Ridgway considers the composition of the Artemision Zeus "inconceivable" as a cult statue: "first, because a figure in action is not compatible with what we know of cult statues in the Fifth century; second, because the action is such as to frighten, not merely to impress the beholder; third, because a cult image at this period would probably be frontal, to establish a direct relationship with the worshipper"." She is also right, I think, to underline the need for an open air setting by this kind of representation of a striding, aggressive god. ${ }^{52}$ For the same reasons the type of an aggressive striding "kriegerische" Athena, the Athena Promachos, as usually represented in the iconography is not appropriate for a cult statue but was meant to be rather an ex-voto placed in the open. ${ }^{53}$ Gabriel Nick would like to see the cult statue of the "Urparthenon" in the figure of Athena as she is depicted on the Panathenaic amphoras. ${ }^{51}$ This seems rather impossible for the reasons provided above. Also Herington connected the striding pose of Athena Promachos (as seen on the Panathenaic amphoras and in the bronze statuettes) with the cult statue of Athena on the Acropolis not taking into account the above-mentioned difficulties. ${ }^{55}$

The difficulty would be overcome, I think, if we accepted that the "striding-god" type was exclusively used for free standing large size votive statues and for small size portable cult images. ${ }^{56}$ Small and portable were the statues of Zeus at Aigion and Messene as we have pointed out above. Portable images of Zeus and Dione as well seem to have existed side by side with their firmly fixed marble cult statues. A small size cult image of the striding Zeus may have existed in Olympia not only before the colossal chrysele-

AGALMA. Studies on ancient Sculpture in honour of George Despinis, Thessaloniki, 2001, p. 99121, fig. 1 with earlier bibliography and the various interpretations proposed so far including his own which seems to be well documented.

51 RIDGWAY (supra n. 50), p. 62.

52 Ibid., p. 62-63, fig. 98-99; Gross (supra n. 37), p. 13-19. Cf. K. NIKOLAOU, OAth 5 (1964), p. 37-45, pl. 1-3; SINION (supra n. 29), p. 32.

53 C. ROLLEY, "Statuettes d'Athéna Promachos", RA (1968), p. 35-48; A. GreifenHAGEN, Griecbiscbe Götter; Berlin, 1978, 11, colorplate I; E. SIMON (supra n. 29), p. 188-189, fig. 169-172 (= terracotta statuettes of Athena Promachos of the 7th c. B.C. from the acropolis of Gortys on Crete in the Heracleion Museum, as well as a bronze statuette of Promachos from the Athenian Acropolis dated to about 550 B.C. in the National Museum of Athens, and another one from the Acropolis dated to $480 / 70$ B.C.); c/. M. JOST, "Statuettes de bronze archaiques provenant de Lycosoura", BCH 99 (1975), p. 339-364; KEESLING (stupra n. 42), p. 81-85.

54 "Die Athena Parthenos - ein griechisches Kultbild", in HÖPFNER (supra n. 27), p. 24 (short version of his Mainz dissertation 1994).

55 C.J. Herington, Atbena Promachos and Atbena Polias, Manchester, 1956; cf. E. Harrison's review of Herington's book in $A / A 61$ (1957), p. 208-209, who rejects his proposition. Against Herington's proposition is also E.K. BORTHwск, "Two notes on Athena as protectress", Hermes 97 (1969), p. 385-391, and G. PINNEY, "Pallas and Panathenaea", in J. CHRISTIANSEN and T. MELANIDER

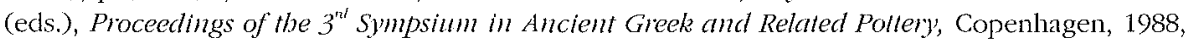
p. $465-477$.

56 Gross (supra n. 37). 
phantine Pheidian statue of the seated Zeus but also after that and was used in ritual processions.

The Ugento Zeus made of hollow bronze, only $0.71 \mathrm{~m}$ high, dated in the late $6^{\text {th }}$ - early $5^{\text {th }}$ century B.C., could be taken as an example of a small size cult image which could be easily transported if needed. ${ }^{57}$ A similar small and portable hollow-cast bronze statue of about the same size was recently found fallen in front of the stone base of a lost firmly fixed large cult statue, inside the cella of the temple of Apollo at ancient Metropolis in Thessaly; it is interpreted as Apollo in full armour and dated around the middle of the $6^{\text {th }}$ century B.C.; the god represented in an aggressive striding pose holding a spear in his raised right hand. ${ }^{58}$

\section{Limnatis and Laphria}

The most detailed account of a fire festival given by Pausanias is not the festival of the Kouretes at Messene but that of Laphria at Patras as mentioned above (Paus., IV, 31, 7). ${ }^{59}$ The cult of this Goddess came first to Messene and later, in the Augustan period, to Patras from Kalydon where it existed since Geometric times with the earliest temple being built at Kalydon probably in the 7 th century $\mathrm{BC}$. The temple was constructed close to a water spring, as was the case with the temple of Artemis at Brauron. ${ }^{60}$ The chryselephantine statue of the goddess Laphria, a work of Menaichmos and Soïda from Naupaktos, of c. 460 B.C., was transferred to Patras on command of Augustus, according to Pausanias (Paus., VII, 18, 8-10 ). ${ }^{11}$ The Messenians returned from

57 N. Degrassi, "Lo Zeus stilita di Ugento", Archaeologia 25 (1981), p. 32; MATTUSCH (supra n. 20 ), p. 68 , fig, 4.17 .

${ }^{58}$ B.G. InTZEsiloglou, "A Newly Discovered Archaic Bronze Statue from Metropolis (Thessaly)", in C.C. MATTUSCH, A. BRAURR and S.E. KNUDSFiN (eds), From the Pants to the Whole I. Acta of the $13^{\text {th }}$ Inlenational Bronze Congress, Cambridge Wassachusetts, May 28-fune 1, 1996, Portsmouth R1, 2000, p. 65-68; id., "The Archaic Temple of Apollo at Ancient Metropolis (Thessaly)", in M. STAMATOPOUlOU, M. XAGORARI (eds.), Excavating Classical Cullure: Recent Archaeological Discoveries in Greece, Oxford, 2002, p. 109-115, pl. 30.

59 M.P. NiLsSON, "Fire-Festivals in Ancient Greece", JHS 43 (1923), p. 144-148; G. PiCCAGULA, "L'olocausto di Patrai" in Le sacrifice dans l'antiquité classique, Genève, 1981 (Eniretiens sur. l'Antiquité classique, 27), p. 243-277.

(6) F. POUlSEN, K. RHOMaIOS, "Erster vorläufiger Bericht über die dänisch-griechischen Ausgrabungen von Kalydon", DVSM 14, 3 (1927), p. 348; E. DygGve, F. POUlSeN, Das Laphrion, der Tempelbezirla von Kalyclon, mit einem religionsgeschichtlichen Beitrag von $F$. Poulsen, Kopenhagen, 1948, p. 161-163, 238, 352-335; EAA IV (1961), s.v. Kalydon (L. VLAD BORELLI); W.K. PrITCHETt, Greek Archives, Cults and Topograpby, Berkeley, 1996, p. 113; Burkert (supra n. 10), p. 62; Antonetti (supra n. 39), p. 245-269; A. MazARakis, From Rulers' Divellings lo Temples: Arcbilecture, Religion and Sociely in Early Iron Age Greece (110-700 B.C.), Jonsered, 1997, p. 95 and 310, fig 38; D. DAvaskos, Untersuchungen zu bellenistischen Kullbilders, Stuttgat, 1999 , p. $52-55$.

61 J. HerbiLlon, Les cultes de Patras, Baltimore, 1929, p. 62-64 argues that the Artemis Laphria depicted on the coins of Patras was not the original statue of the goddess brought in from Kalydon but a later, probably Hellenistic version. 
the exile brought with them not only the portable cult image of Zeus but introduced also the cult of Laphria to their new home (Paus., IV, 31, 7). ${ }^{62}$

A sanctuary excavated by Philippe Le Bas in 1843 and considered as lost was rediscovered in 1988. It is located on the SE slope of mount Thome, at a place called "Spelouza", close to an ancient water spring. ${ }^{63}$ The landscape, mountain plateau and water spring, is similar to the Aetolian landscape in which the Laphrion at Kalydon was located. The discovery of two inscriptions (only one found in the area of the sanctuary itself) led Le Bas to the identification of the sanctuary with that of Artemis Limnatis and Laphria. ${ }^{6 i}$ Pausanias does not mention the epigraphically attested eponym of Limnatis, but only that of Laphria Artemis, adding that her cult statue was a work of Damophon (IV, 31, 7). Omitting one of the eponyms of the goddess is a practice not quite unusual for Pausanias, also the exclusively as Orthia attested Artemis worshipped in Cult Room $\mathrm{K}$ of the Asklepieion is only called Phosphoros by him. ${ }^{65}$

The temple excavated by Le Bas has the form of a distylos in antis, measuring $16.70 \times 10.60 \mathrm{~m}$, and combining ionic with Corinthian architectural traits, the workmanship and profiles of which allow a date to the end of the $3^{\text {rd }}$ century B.C. The limestone base of the cult statue is still preserved in situ inside the rectangular, $8 \times 9 \mathrm{~m}$, cella. It should have supported a life-size cult statue, as its dimensions, $1.30 \times 1.13 \mathrm{~m}$ with a height of $0.95 \mathrm{~m}$, indicate. The altar and remains of three more buildings (porticos?) have been revealed on the east and south sides of the precinct. As Hans Lauter points out, the closed pronaos of the temple forms an architectural preludium, an introduction to the main point of interest, i.e. the cult statue centrafly placed inside the cella. ${ }^{66}$ Similar ideas of space organisation and of the dialectic relation between architecture and sculpture prevail in the contemporary sanctuary of the Asklepieion where Damophon mainly worked. ${ }^{67}$ The statue of Laphria was made by the same Messenian sculptor as we mentioned above.

62 W. OTTo, De sacris Messenionum, Halle, 1933, p. 46; C.A. RoEBuck, A History of Messenia from 369 to 146 B.C., Chicago, 1941, p. 34.

${ }^{63}$ Ph. LE BAS, RA 1 (1844), p. 422-425; id., "Temple de Diane Laphria à Messène", in S. REINACH, Voyage archéologique en Grèce et en Asie Mineure sous la direction de M. Philippe Le Bas membre de l' Instilut (1842-1844), Paris, 1888, p. 134-138, pl. I.7; THEMElis, Prakt (1988), p. 72, fig. 15, pl. 57a-b; E.L. BrulotTE, The Placement of Votive Offerings and Dedications in the Peloponnesian Sanctuaries of Artmis (Diss.), Minnesota, 1994, p. 253-255.

61 A. WILHELM, "Inschriften aus Messene", MDAI(A) 16 (1891), p. 351, mentions fragments of a colossal statue which have not been found up to now either at the site or in the storerooms of the local Museum; cf. Damaskos (supra n. 60), p. 43-44.

65 THENELIS (sipra n. 35), p. 101-122.

6. H. LAUTER, Die Architektur des Hellenismus, Darmstadt, 1986, p. 195.

${ }^{67}$ P. THEMELIS, "Damophon von Messene. Sein Werk im Lichte der neuen Ausgrabungen", AntK 36 (1993), p. 24-40; id., "Damophon of Messene. New Evidence", in K. SHEEDY (ed.), Archaeology in the Peloponnese. New Excavations and Research, Oxford, 1994, p. 1-37; id., "Damophon", in O. Palagia, J.J. PollitT (eds.), Personal Styles in Greek Sculpture, Oxford, 1996, p. 154-187. 
The sanctuary was used by the city officials, the ephoroi, to publish acts of manumitio, liberation of slaves, especially females, as several inscriptions of this kind dated to the $3^{\text {rd }}$ century B.C. indicate. ${ }^{68}$ This can be taken as additional evidence of the importance the sanctuary had for the city of Messene. Manumitions were also taken place in the great Aetolian sanctuary of Artemis Laphria at Kalydon. ${ }^{69}$ All aspects and characteristics of the primitive Aetolian cult of Laphria ingeniously analysed by scholars, such as protection of the wild animals and plants, of marriage, pregnancy and initiation rites, as well as the holocausts, reveal a potnia dominating over the forces of fertility and fecundity in the world of men, animals and plants. ${ }^{70}$ The most appropriate place of worshiping this goddess at Messene would be the natural environment of the forested mount Ithome, inside the walls but outside the inhabited area of the city, and in the vicinity of the sanctuary of Eileithyia and the Kouretes.

Petros THEMELIS

Centre of Messenian Archaeological Studies

Psaromiligou Str. 33

GR - 10553 AT'HENS

pthemelis@botmail.com

6s $I G \mathrm{~V} 1,1470,1471$ and 1472.

69 IG IX, I' 1,137 ; ANTONETTI (supra n. 39), p. 265.

${ }^{70}$ Dyggve - Poulsen (supra n. 60), p. 161-163, 238, 352-335; ANTONETTt (supra n. 39), p. 253-257; c/. NiLSSON (supra n. 59), p. 144-148; PicCALuga (supra n. 59), p. 243-277. 